\title{
ASSESSMENT OF SERUM LIPID PROFILE IN HYPERTENSIVE PATIENTS: A CASE-CONTROL STUDY
}

\author{
Sushma Reddy $V^{1}$, Hari Prasad TV ${ }^{2}$, Surendra BV \\ ${ }^{I}$ Department of Biochemistry, Koppal Institute of Medical Sciences, Koppal, Karnataka, Inida. \\ ${ }^{2}$ Assistant Professor, Department of Physiology, Viswa Bharthi Medical College, Kurnool, Andhra Pradesh, India.
}

\section{ABSTRACT}

Background: Hypertension and dyslipidemia are strongly associated with each other, and they are the most common risk factors for the development of the cardiovascular disease. Aim: Compare the serum lipid profile values among hypertensive patients and non-hypertensive individuals. Method: 30 patients with Hypertension and 30 age-matched non-hypertensive controls were included in the study. From the serum, total cholesterol levels were estimated by enzymatic (CHOD-PAP) colorimetric method, triglyceride by enzymatic (GPO-PAP) method, HDL-cholesterol and LDL-cholesterol were estimated using precipitant and Friedewald formula, by using commercially available reagent kits. Lipid profiles were compared with controls. Results: The mean values of total cholesterol were significantly more in Hypertensives-202.93 \pm 28.44 and normotensives-178.76 $\pm 37.21, \mathrm{P}<0.006$. The mean values of triglycerides were significantly more in Hypertensives- $139.8 \pm 18.72$ and normotensives- $125.8 \pm 12.34, \mathrm{P}<0.001$. The mean values of LDL-Cholesterol were significantly more in Hypertensives-141.63 \pm 11.59 and normotensives-127.83 \pm 14.65, $\mathrm{P}<0.0001$. Conclusions: As Dyslipidemia is associated with Hypertension, serum lipid profile may be useful in the identification of patients at risk of Hypertension. Hypertensive patients need the measurement of blood pressure and lipid profile at regular intervals to prevent Cardiovascular diseases.

Keywords: Cholesterol; Cardiovascular Diseases; Hypertension; Triglycerides; Dyslipidemia.

\section{INTRODUCTION}

Across the world, Hypertension is one of the most common risk factors for cardiovascular disease (CVD) [1] hypertension is more in developing countries, due to rapid urbanization, unhealthy diet, and lifestyle changes that have lead to an increased rate of CVD in Southeast Asia, including India [2]. According to the World Health Organization (WHO) report, India, by 2020, CVDs will be the leading cause of disability and death. Around 2.6 million people in India are expected to die due to coronary heart diseases by 2020 [3].

The association between hypertension and dyslipidemia is well established, and both may add up to increase patient's susceptibility to the development of Coronary Heart Disease (CHD). Hypertension is prone to cause Coronary Vascular Disease (CVD) in person with added risk factors such as elevated serum cholesterol. People with high blood pressure have more chances to have lipid abnormality than those with normal blood pressure [4].

Increased levels of triglyceride, cholesterol, and LDL-C are documented as risk factors for atherogenesis [5]. LDL-C in its oxidized or acetylated form has been identified as a significant atherogenic particle, as it not only loads macrophages with cholesterol for the formation of foam cells but also because it is

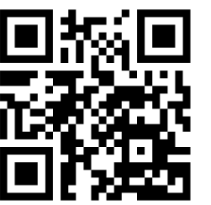

DOI: $10.31878 /$ ijcbr.2019.61.06

eISSN: 2395-0471

pISSN: 2521-0394 chemotactic for circulating monocytes, it is cytotoxic and can adversely alter coagulation pathways [6]. The blood level of HDL-C, in contrast, bears an inverse relationship of the risk of atherosclerosis and coronary heart disease that is higher the level, smaller the risk [7]. The objective of the study was to compare the lipid profile in Hypertensive patients and non-hypertensive individuals.

\section{MATERIAL AND METHODOLOGY}

Study design: Case-control analytical study

Ethics: This study was initiated after obtaining consent from the patients and healthy volunteers and prior approval by the Institutional Ethical Committee.

Study duration: November 2018 to January 2019.

Study place: Koppal Institute of Medical Sciences \& Hospital, Karnataka

Sample size: A total number of 60 human subjects of age ranging from 30-60 years were included in this study.

Inclusion criteria: Participants were randomly selected from the OP of General Medicine. Patients with systolic blood pressure above $140 \mathrm{mmHg}$ or diastolic blood pressure above $90 \mathrm{mmHg}$ were considered hypertensive patients.

Exclusion criteria: Patients with diabetes mellitus, pregnant woman, Renal disorders, Rheumatoid arthritis, active hepatic disease, on oral contraceptives, on thiazide and/or beta-blockers, and any patients on lipid-lowering drugs.

Correspondence: Sushma Reddy. Department of Biochemistry, Koppal Institute of Medical Sciences, Near Gangavathy road, Koppal, Karnataka, Inida. Email: sushmareddyv6@gmail.com 
Grouping: Out of the 60 subjects, 30 newly diagnosed hypertensive patients(cases) and the equal number of age and sex-matched without hypertension were selected as controls.

Measurements: B.P was measured using a standard BP measurement protocol after the patient had rested for 10 minutes. Blood pressure was recorded on the left arm in a sitting position using a standard mercury sphygmomanometer; systolic (SBP) and diastolic (DBP) blood pressures corresponded to Korotkoff sounds 1 and V, respectively.

Biochemical analysis: Five milliliters $(5 \mathrm{ml})$ venous blood was obtained between 08:00 and 09.00 a.m. after a 12-hour fasting period. The blood was allowed to clot for one hour. Centrifugation was done to separate the serum for 10 minutes, after which serum was isolated into a dry plain plastic screw-capped container and refrigerated (at $-20^{\circ} \mathrm{C}$ ) before analyses. The analysis was done on fully auto analyzer XL 640 in Biochemistry Lab.

Serum total cholesterol levels was determined by enzymatic (CHOD-PAP) colorimetric method [8] and triglyceride by enzymatic (GPO-PAP) method [9] HDL-cholesterol and LDL-cholesterol were estimated using precipitant [10] and Friedewald formula [11,12]. Above all, parameters under investigation were determined in the serum of patients and controls using commercially available reagent kits.

Serum total cholesterol (TC), low-density lipoprotein cholesterol (LDL-C), high-density lipoprotein cholesterol (HDL- C), and triglyceride (TG) levels were classified on the basis of the Third Report of the Expert Panel on Detection, Evaluation, and Treatment of High Blood Cholesterol in Adults (ATP III) [12].

Elevated TC, HDL C, LDL C and TG was defined as having levels of $>5.17 \mathrm{mmol} / \mathrm{L}(200 \mathrm{mg} / \mathrm{dL}),<1.03$ $\mathrm{mmol} / \mathrm{L}(<40 \mathrm{mg} / \mathrm{dL}),>3.38 \mathrm{mmol} / \mathrm{L}(>130 \mathrm{mg} /$ $\mathrm{dL}),>1.69 \mathrm{mmol} / \mathrm{L}(>150 \mathrm{mg} / \mathrm{dL})$ respectively.

Statistical analysis: By student's " $t$ " test statistical significance was evaluated between control and study groups. $\mathrm{P}<0.05$ was considered to be statistically significant.

\section{RESULTS}

Table 1: Age Distribution for Cases and Controls

\begin{tabular}{lll}
\hline \multirow{2}{*}{ Age in Years } & Controls & Cases \\
\cline { 2 - 3 } $31-40$ & $\mathrm{~N}(\%)$ & $\mathrm{N}(\%)$ \\
$41-50$ & $5(17)$ & $5(17)$ \\
$51-60$ & $10(33)$ & $10(33)$ \\
Male & $15(50)$ & $15(50)$ \\
Female & $20(67)$ & $20(67)$ \\
\hline
\end{tabular}

Table 2: BP and Lipid profile distribution of Controls and cases

\begin{tabular}{llll}
\hline Category & Controls & Cases & P-value \\
\hline $\begin{array}{l}\text { Systolic B.P } \\
(\mathrm{mm} / \mathrm{Hg})\end{array}$ & $120.4 \pm 11.65$ & $156.13 \pm 8.43$ & $<1.04$ \\
$\begin{array}{l}\text { Diastolic B.P } \\
(\mathrm{mm} / \mathrm{Hg})\end{array}$ & $76.2 \pm 4.11$ & $98.2 \pm 5.85$ & $<1.06$ \\
$\mathrm{TG}(\mathrm{mg} / \mathrm{dl})$ & $125.83 \pm 12.34$ & $139.8 \pm 18.72<0.001$ \\
$\mathrm{TC}(\mathrm{mg} / \mathrm{dl})$ & $178.76 \pm 37.21$ & $202.93 \pm 28.44<0.006$ \\
$\mathrm{LDL}-\mathrm{C}(\mathrm{mg} / \mathrm{dl})$ & $127.83 \pm 14.65$ & $141.63 \pm 11.59<0.0001$ \\
$\mathrm{TG}(\mathrm{mg} / \mathrm{dl})$ & $41 \pm 2.81$ & $32.26 \pm 3.66$ & $<2.02$ \\
\hline
\end{tabular}

Significantly higher levels of serum Triglycerides, serum Cholesterol, serum LDL-Cholesterol and statistically insignificant difference of HDL-Cholesterol were found among Hypertensive patients compared to nonhypertensive individuals.

Table 3: BP and Lipid profile distribution according to sex in Controls and cases

\begin{tabular}{|c|c|c|c|}
\hline Category & Controls & Cases & P value \\
\hline \multicolumn{4}{|l|}{ Men } \\
\hline $\begin{array}{l}\text { Systolic B.P } \\
(\mathrm{mm} / \mathrm{Hg})\end{array}$ & $\begin{array}{l}117.5 \pm 10.6 \\
7\end{array}$ & $155.2 \pm 7.87$ & $<1.14$ \\
\hline $\begin{array}{l}\text { Diastolic B.P } \\
(\mathrm{mm} / \mathrm{Hg})\end{array}$ & $76.4 \pm 3.64$ & $97.9 \pm 5.21$ & $<1.18$ \\
\hline $\mathrm{TG}(\mathrm{mg} / \mathrm{dl})$ & $\begin{array}{l}126.8 \pm 10.5 \\
8\end{array}$ & $138 \pm 20.52$ & $\begin{array}{l}<0.03 \\
8\end{array}$ \\
\hline $\mathrm{TC}(\mathrm{mg} / \mathrm{dl})$ & $\begin{array}{l}177.1 \pm 36.7 \\
5\end{array}$ & $\begin{array}{l}198.5 \pm 27.2 \\
1\end{array}$ & $\begin{array}{l}<0.00 \\
4\end{array}$ \\
\hline LDL-C (mg/dl) & $\begin{array}{l}130.5 \pm 15.6 \\
3\end{array}$ & $\begin{array}{l}143.3 \pm 11.9 \\
2\end{array}$ & $\begin{array}{l}<0.00 \\
5\end{array}$ \\
\hline $\begin{array}{l}\text { HDL-C (mg/ } \\
\text { dl) } \\
\text { Female }\end{array}$ & $40.55 \pm 2.94$ & $32.55 \pm 4.13$ & $<3.91$ \\
\hline $\begin{array}{l}\text { Systolic B.P } \\
(\mathrm{mm} / \mathrm{Hg})\end{array}$ & $126.2 \pm$ & $158 \pm$ & $<4.64$ \\
\hline $\begin{array}{l}\text { Diastolic B.P } \\
(\mathrm{mm} / \mathrm{Hg})\end{array}$ & $75.8 \pm$ & $98.8 \pm$ & $<4.06$ \\
\hline $\mathrm{TG}(\mathrm{mg} / \mathrm{dl})$ & $124 \pm$ & $143.5 \pm$ & $<0.01$ \\
\hline $\mathrm{TC}(\mathrm{mg} / \mathrm{dl})$ & $182.1 \pm$ & $211.8 \pm$ & $\begin{array}{l}<0.07 \\
7\end{array}$ \\
\hline LDL-C (mg/dl) & $122.5 \pm$ & $138.2 \pm$ & $<0.05$ \\
\hline $\begin{array}{l}\text { HDL-C (mg/ } \\
\text { dl) }\end{array}$ & $41.9 \pm$ & $31.7 \pm$ & $<3.72$ \\
\hline
\end{tabular}

DISCUSSION

In this present study, serum lipid profiles of hypertensive patients and healthy volunteers were estimated. Significantly higher levels of serum cholesterol, triglyceride and LDL-cholesterol were found in hypertensive patients than those of the control group, and no statistically significant difference of HDL-Cholesterol was found in hypertensive patients than those of the control group. Regular evaluation of lipid profile is a must in all hypertensive cases to stop further aggravation and risk of CVDs. 
Table 4: BP and Lipid profile distribution according to age in Controls and cases

\begin{tabular}{llllllllll}
\hline Category & $\mathbf{3 1 - 4 0}$ & \multicolumn{7}{c}{$\mathbf{4 1 - 5 0}$} & \multicolumn{5}{c}{$\mathbf{5 1 - 6 0}$} \\
\cline { 2 - 9 } & Controls & Cases & P value & Controls & Cases & P value Controls & Cases & P value \\
$\begin{array}{l}\text { Systolic B.P } \\
\text { (mm/Hg) }\end{array}$ & $116.8 \pm 4.38$ & $150.4 \pm 4.33$ & $<1.9$ & $116.2 \pm 11.9$ & $158 \pm 8.74$ & $<7.68$ & $124.4 \pm 12.26$ & $156.8 \pm 8.84$ & $<1.19$ \\
$\begin{array}{l}\text { Diastolic B.P } \\
(\mathrm{mm} / \mathrm{Hg})\end{array}$ & $75.6 \pm 2.96$ & $100.8 \pm 3.34$ & $<1.48$ & $76.4 \pm 4.69$ & $97.4 \pm 4.52$ & $<6.76$ & $76.2 \pm 4.26$ & $97.8 \pm 7.18$ & $<7.56$ \\
$\mathrm{TG}(\mathrm{mg} / \mathrm{dl})$ & $122.4 \pm 10.78$ & $161.4 \pm 34.1$ & $<0.64$ & $123.7 \pm 13.1$ & $136.5 \pm 12.13$ & $<0.036$ & $128.4 \pm 12.5$ & $146.6 \pm 21.5$ & $<0.009$ \\
$\mathrm{TC}(\mathrm{mg} / \mathrm{dl})$ & $161.4 \pm 34.13$ & $182 \pm 27.43$ & $<0.32$ & $177.3 \pm 21.9$ & $187.5 \pm 24.55$ & $<0.34$ & $185.5 \pm 45.47$ & $220.2 \pm 20.67<0.014$ \\
LDL-C (mg/dl) & $120.4 \pm 18.52$ & $151 \pm 16.73$ & $<0.025$ & $132.3 \pm 17.6$ & $137.4 \pm 11.4$ & $<0.45$ & $127.3 \pm 10.66$ & $141.33 \pm 8.37<0.000$ \\
HDL-C (mg/dl) & $41.2 \pm 2.28$ & $34.6 \pm 4.56$ & $<0.27$ & $40.2 \pm 3.48$ & $32.3 \pm 4$ & $<0.000$ & $41.4 \pm 2.53$ & $31.4 \pm 2.99$ & $<1.87$ \\
\hline
\end{tabular}

These findings of Significantly higher levels of serum cholesterol, triglyceride, and LDL-cholesterol in hypertensive patients than those of the control group were entirely in agreement with the results of some previous studies.

Sabri [13], and Yin [14], showed that total cholesterol level was higher in hypertensive patients than nonhypertensive subjects.

Shahadat et al., [15] Adedeji et al., [16] and Shah et al. [17] in their respective studies showed that total cholesterol and triglycerides were higher in hypertensive patients

Oparil et al. explained different mechanisms through which dyslipidemias may cause hypertension over time. First, arteriosclerosis in the larger arteries due to the hypertrophy of smooth muscle cells and deposition of collagen leads to arterial stiffness. This may lead to increased SBP seen with increasing age. Besides, a healthy endothelium responds to intravascular cues whether to dilate or constrict. Hypertensive patients have increased vascular reactivity [18], Dyslipidemias lead to endothelial dysfunction and improper vasoregulation [19], as production, release and subsequent activity of nitric oxide are decreased among those with more $\mathrm{TC}$ and less HDL-C levels. And also, endothelium-dependent vasodilatation is inversely correlated with TC levels [20]. Besides, dyslipidemia can also cause damage to the renal microvasculature with the effect of hypertension. dyslipidemia is linked to renal decline [21].

However, no statistical significance of HDL-Cholesterol was found among Hypertensive patients in comparison with the healthy volunteers.

\section{CONCLUSION}

Dyslipidemia is associated with hypertension. Hypertension and dyslipidemia can be modified either by proper lifestyle changes or medical management or by the combination of both. This study recommends that hypertensive patients need the measurement of blood pressure and lipid profile at regular intervals to prevent cardiovascular diseases.

Acknowledgment: The author wishes to thank Dr. Amareshwara M Malagi, Professor \& HOD, Department of Biochemistry for his valuable suggestion $\&$ technicians of Biochemistry lab, for laboratory help.
Conflict of interest: Nil

Source of funding: Nil

\section{REFERENCES}

[1] He J, Whelton PK. Epidemiology and prevention of hypertension. Med Clin North Am. 1997;81:1077-97

[2] Joshi P, Islam S, Pais P, Reddy S, Dorairaj P, Kazmi K, et al. Risk factors for early myocardial infarction in South Asians compared with individuals in other countries. JAMA. 2007;297 (3):286-94

[3] Kumar A, Nagtilak S, Sivakanesan R, Gunasekera S. Cardio-vascular risk factors in elderly Normolipidimic acute myocardial infarction patients - A case-controlled study from India. Southeast Asian J Trop Med Public Health. 2009;40(3):581-92

[4] Wannarinthee SC, Shaper AG, Durington PN, Perry M. Metabolic Syndrome. J. Human Hypertension, 1998;12(2): 1059-64.

[5] Lipid Research Clinic Program. The lipid research clinic coronary primary prevention trial results II. J.Am. Med. Assoc. 1984;251:364-74.

[6] Fogelman A, I. Schechter J. Seager. Alteration of low density lipoproteins leads to cholesterylester accumulation in human monocyte macrophages. Proc. Natl. Acad. Sci., USA, 1980;77:2214-8

[7] Palinski W, Rosenfeld M, Yla-Herttuala S. Low density lipoprotein undergoes oxidative modification in vivo. Proc.Natl. Acad. Sci., USA. 1989;86:1372-6.

[8] Allain CC, Poon IS, Chan CHG, Richmond W, Fu PC. Enzymatic determination of serum total cholesterol.Clin. Chem. 1974; 20: 470-1

[9] Jacobs NJ, VanDenmark PJ. Enzymatic determination of serum triglyceride.ch. Biochem. Biophys. 1960;88:250-5.

[10] Gordon T and Gordon M, Enzymatic method to determine the serum HDL-cholesterol. Am. J. Med. 1977; 62: 707-8

[11] Friedewald WT, Levy RI, Fredrickson DS. Estimation of the concentration of LDLcholesterol. Clin. Chem. 1972;18 (6): 499-515 
[12] Third Report of the National Cholesterol Education Program (NCEP), "Expert panel on detection, evaluation, and treat- ment of high blood cholesterol in adults (Adult Treatment Panel III) final report," Circulation, 2002; 106: 3143-421.

[13] Sabri S, Bener A, Eapen V, Abu Zeid MS, AlMazrouei AM, Singh J. Some risk factors for hypertension in the United Arab Emirates. East Mediterr Health J. 2004; 10(4-5):610-9

[14] Yin R, Chen Y, Pan S, He F, Liu T, Yang D, et al. Comparison of lipid levels, hyperlipidemia prevalence and its risk factors between Guangxi Hei Yi Zhuang and Han populations. Arch Med Res. 2006;37(6):787-93.

[15] Shahadat H, Maliha R, Iqbal A, Suhrab A. Study of serum lipid profile in essential hypertensive patients. Mym Med J. 1999;8(1):22-5.
[16] Adedeji OO, Onitiri AC. Lipids in Nigerian hypertensives. Afr J Med Sci. 1990;19:281-4.

[17] Saha MS, Saha NK, Shaha RK. Serum lipid profile of hypertensive patients in the northern region of Bangladesh. J Biosci. 2006;14:93

[18] Oparil S, Zaman MA, Calhoun DA. Pathogenesis of hypertension. Ann Intern Med. 2003;139:761-76.

[19] Selwyn AP, Kinlay S, Libby P, Ganz P. Atherogenic lipids, vascular dysfunction, and clinical signs of ischemic heart disease. Circulation. 1997;95:5-7.

[20] Vallance P, Collier J, Moncada S. Effects of endothelium-derived nitric oxide on peripheral arteriolar tone in man. Lancet. 1989;2:997-1000.

[21] Schaeffner ES, Kurth T, Curhan GC, Cholesterol and the risk of renal dysfunction in apparently healthy men. J Am Soc Nephrol. 2003;14:2084- 91. 